\title{
THE LISBON TREATY AND THE BRITISH PRESS A CORPUS-BASED CONTRASTIVE ANALYSIS OF EVALUATION RESOURCES
}

\author{
CHIARA NASTI \\ Università degli Studi di Napoli \\ chiara.nasti@unina.it \\ MARCO VENUTI \\ Università degli Studi di Napoli \\ venuti@unina.it
}

\section{Introduction}

This paper is based on the results of an earlier research which has proved that metaphors can be employed by the British press to construe the event of the Lisbon treaty ratification and might be a useful linguistic tool to explore different attitudes towards that event (Nasti 2010). On the premises that metaphors are connected to evaluation as they are manifestations of the writer's or speaker's intentions, the present paper will investigate those evaluative resources that have been found to co-occur with the metaphors previously analyzed in order to explore how the British press uses these resources to construe the event of ratification and to what extent it presents a similar description or attributes similar roles to the European leaders.

This paper is divided into six sections. The first section provides a general overview of the main stages towards the ratification of the Lisbon Treaty. The second, after giving a definition of evaluation, briefly describes the results of the previous research. The third part provides information on data collection and the theoretical background. The fourth and the fifth sections deal with the analysis of the evaluative lexis. The conclusions indicate that metaphors and evaluation are both used to create a coherent text and image of the ratification issue.

\section{Political Background}

\subsection{Towards the drafting stage of the Lisbon Treaty}

In recent years EU member states have been deeply debating how to implement and reform EU institutions. After the rejection of the European Constitution by France and The Netherlands in 2005, the European Commission declared a "period of reflection". At 
the end of these years, the European Council of 21 and 22 June 2007 decided to convene an Intergovernmental Conference (IGC) to finalize and adopt a new European Treaty. The IGC officially began its work on 23 July 2007 and concluded on 18 October of the same year with the draft of a Reform Treaty. This Treaty, later named Lisbon Treaty, was signed by all the Heads of State and Government of the 27 Member States of the European Union on 13 December 2007 in Lisbon. All the European Countries were expected to ratify the Treaty by the end of the year 2008 so that the Treaty would enter into force on 1 January 2009.

\subsection{The ratification of Lisbon and the Irish referendum}

A few days after the Treaty signing ceremony, Hungary was the first member state to approve the treaty via parliament. This approval was followed by other positive outcomes and by the end of June 2008 eighteen member states had approved the Treaty and eight of them had also deposited the instruments of ratification in Rome. ${ }^{1}$ However, the ratification of the Treaty was not welcomed by all the member states and their citizens. In Britain (see 1.3) the Tories advocated for a referendum and strongly opposed the ratification procedure. While Ireland, which was obliged by its Constitution to hold a referendum, saw opponents and supporters of the Lisbon Treaty challenging the vote and pleading for their own cause. The Irish Prime Minister, Brian Cowen, and the political parties (Fine Gael, Fianna Fail, Labour and Progressive Democrats) supporting the yes vote, put emphasis on the importance for Ireland and the Irish People to vote in favour of the Treaty in order to stay at the centre of Europe and have a leading role in the decision making process. On the other hand, the anti-Lisbon think thank Libertas Group and the other political parties (Sinn Féin, Socialist Party) supporting the no vote, emphasized the necessity of defending important social issues such as the tax policy, abortion and neutrality which would be lost by approving the Treaty. The referendum was held on June 12, 2008 and as it was expected, the turnout was negative with $53.4 \%$ 'no' and $46.6 \%$ 'yes' votes. After the referendum, a flash Eurobarometer survey was conducted from 13 to 15 June as requested by the European Commission Representation in Ireland. It emerged that many Irish citizens had no clear idea of the Treaty's content and the referendum's issues, and $68 \%$ of the voters said that the 'no' campaign was the more convincing. Nevertheless, something had gone wrong and EU leaders had to face the consequences of the Irish rebuff.

${ }^{1}$ The Member States that had approved the Treaty before 12 June 2008 were Poland, Slovakia, Portugal, Latvia, Lithuania, Germany, Luxemburg, Finland, Greece, and Estonia. Malta, Hungary, France, Romania, Slovenia, Bulgaria, Austria, and Denmark had also completed the ratification. Further references at http://europa.eu/lisbon_treaty/news/index_en.htm and http://europa.eu/lisbon_treaty/countries/index_en.htm. 


\subsection{The ratification of Lisbon in Britain}

The disapproval of the Lisbon Treaty by the Conservatives and British citizens had been visible since the negotiation period. Both the Tories and British people expected a referendum on the issue as it had been promised by the Labour Party in its electoral campaign in 2005. The idea of the Lisbon Treaty as a 'revised' or 'repackaged' constitution, was commonly agreed among the Conservatives and British citizens. As a consequence, in the long process of ratification, the Tories tried to oppose the parliamentary procedure and on 5 March proposed an amendment calling for a referendum which was defeated by 311 votes to 248 . On the third reading, 11 March 2008, the House of Commons approved the treaty which passed to the Lords. The Tories began to see the Lords as the only possibility to put an end to the ratification process and definitely abandon the Treaty.

The dispute on the legality of adopting the treaty without a referendum had already been brought to the fore by the British multi-millionaire Stuart Wheeler soon after the signing ceremony in Lisbon. He brought that case before the High Court, questioning whether a political party's election manifesto was legally enforceable. Despite Tories' pleas for suspending ratification, the British Prime Minister, Gordon Brown, slowly continued with the ratification procedure. Wheeler's hearing was held on June 9 and 10 a few days before the Irish referendum. The High Court refused Wheeler's petition and the House of Lords passed the bill ratifying the Treaty on 18 June 2008, marking a remarkable moment for the British citizens who saw their rights of voting denied. The Treaty received Royal Assent the following day and the instruments of ratification were deposited on 16 July 2008. The ratification of Lisbon in Britain was then completed.

\subsection{From the first referendum towards a solution}

Ireland's referendum rebuff put the European Union in a kind of 'institutional crisis' and all the EU leaders questioned whether it was still possible to have a reformed Europe. Soon after the referendum in fact, EU leaders gather together at the European Council Summit of June 18-19 where it was agreed that Ireland would find a solution at a national level and would cooperate with the other European member states in order to achieve the intended goals. On July 1 Nicholas Sarkozy, the French Prime Minister, took the rotating EU presidency and declared that his primary aim was to continue with ratification. On July 21 he visited Ireland and met the Irish Prime Minister, Brian Cowen, in order to discuss Irish proposals for the October Summit. However, at the October Summit the Lisbon issue was postponed to the next Summit because the core of the meeting was the increasing financial crisis in Europe. At the Brussels Summit of 11 and 12 December 2008, EU leaders discussed the new roadmap for the Treaty of Lisbon. It was agreed that, once the Treaty entered into force, a decision would be taken to allow each EU country to nominate a member of the European Commission. Furthermore, the Irish government committed itself to organizing a new referendum before November 2009 in exchange for guarantees from its EU partners.

After a period of political turmoil, which saw many European member states such as Poland, and in particular its President Lech Kaczynski, the Czech Republic supporting 
the Irish NO, and the British Conservatives opposing the ratification in Britain, the Lisbon Treaty was passed in the referendum held on 2 October 2009 in Ireland. This event marked a new progress towards the ratification and after all the member states deposited the instruments of ratification in Rome, the Treaty entered into force on 1 December 2009.

Even though the Lisbon issue has been on the European political agenda for more than two years, the present paper only investigates the first referendum period.

\section{Evaluation}

Evaluation plays an important role in understanding speakers or writers' attitude towards an event or their feelings about entities and propositions (Hunston \& Thompson 2000). Bednarek (2006) argues that evaluation permeates human behaviour and is linked to our beliefs. She also points out the importance of evaluation in actual discourse as it is impossible for any human being not to judge or to be completely objective on a particular event:

evaluation itself is a significant element of our lives: as a device for interpreting the world and offer this evaluation to others. It pervades human behaviour [...] evaluation is extremely important in actual discourse, in that it is difficult if not impossible for human beings $[\ldots]$ to speak with a completely objective voice. (Bednarek 2006: 5)

Due to the relationship between evaluation and our beliefs, it can be argued that there is a close link between evaluation and metaphor, as metaphor analysis

is often, then, an exploration of the inner subjectivity of speakers - what it is that is unique to their perception of the world - and forms the basis for their response to particular situations and particular ideas"' (Charteris-Black 2004: 11).

Against this framework, this paper starts from the findings of a research project on conceptual metaphor analysis in the British press related to the Lisbon Treaty debate (Nasti 2010) and focuses on the evaluative lexis that has often been found to collocate or co-occur with the linguistic expressions of the conceptual conflict metaphor ARGUING ABOUT THE RATIFICATION OF LISBON IS CONFLICT. It has been decided to analyze those lexemes that more than others tend to express the conflicting attitude of the speaker. As a consequence, we have focused on evaluative verbs such as 'to bully' and 'to blast' in all their forms and on evaluative adjectives such as 'arrogant' and 'reluctant'. It has also been decided to analyse another evaluative verb that has a positive connotation in itself 'to praise' which has been found to collocate with the other conceptual metaphor analysed in the previous work: LISBON RATIFICATION PROCESS IS MOVEMENT FORWARD/DIRECTION. The results emerged from the analysis of the two metaphors have shown that EU leaders are attributed the stereotyped roles of aggressors using bullying tactics on their victim, Ireland, and of fast movers forcing the path towards Lisbon ratification leaving Ireland behind or in the slow lane passively accepting the action of the EU enforcers. What emerges is a general negative connotation and evaluation of EU leaders and in some newspapers such as The Times, The Daily Telegraph, The Sun and 
The Daily Mail a strong disapproval of both EU leaders and the British Prime Minister who is also stereotyped as an enforcer.

In this framework, the aim of the present paper is to show how a corpus-based analysis of evaluative lexis can be a means to bridging the gap between a context-based interpretation of meaning and the broader conceptual framework of the Lisbon Treaty ratification process. This paper will also try to explore to what extent the event construal of ratification through evaluative resources presents similar scenarios and stereotyped roles of the EU reform process and Leaders.

\section{Data and methodology}

Previous studies (Anderson and Weymouth 1999) have focused on the relationship between the British press and Europe highlighting how a widespread euroscepticism pervades most of the coverage of European issues. Other studies (Musolff 2000, 2001; Musolff, Schäffner, Townson eds. 1996) have more specifically analyzed how specific topics concerning the evolution of European institutions have been dealt with in both the British and the German Press, showing how different conceptual frameworks emerge.

Before presenting our analysis, which falls in line with these outlined trends, we will provide an overview of our corpus, of the methodologies combining Corpus Linguistics and Discourse Analysis approaches, and the specific methodology we followed.

\subsection{The corpus}

The corpus used for the present analysis is the same used for the previous research (Nasti 2010). It consists of 1263 articles taken from fourteen newspapers (three tabloids, i.e. the Daily Mail, The Mirror, The Sun and their Sunday editions, and four broadsheets, i.e. the Guardian, The Independent, The Daily Telegraph and The Times and their Sunday editions). The articles were downloaded from the Lexis Nexis database. The collection of data started on 1 June 2007 because in that month EU leaders gathered together and set the basis for the drafting of the new Treaty and ended on 31 March 2009, that is a month after the first step of ratification in the Czech Republic which was in charge of the EU presidency at that time. Once collected the articles were saved in .txt format in order to be processed by WordSmith Tools (Scott 2008). The articles were then chronologically ordered and divided into sub-corpora, each newspaper was considered to be a sub-corpus. Moreover, XML mark-up was included in order to add metadata about the articles (date of publication and by line, when available) and their structure (headline, paragraph and section). This information will be used in the analysis in the following paragraphs. For the purpose of this paper each newspaper and its Sunday edition were considered to be a single sub-corpus with a different size as shown in Table 1.

\begin{tabular}{ll}
\hline Sub-corpus & No. of Tokens \\
\hline Guardian & 65,900 \\
Mail & 179,992
\end{tabular}




\begin{tabular}{ll}
\hline Sub-corpus & No. of Tokens \\
\hline Sun & 52,110 \\
Times & 150,774 \\
Independent & 54,700 \\
Mirror & 34,233 \\
Telegraph & 69,581 \\
Total & 607,290 \\
\hline
\end{tabular}

Table 1: Number of tokens in each sub-corpus

\subsection{Corpus Linguistics and Discourse Analysis}

For the purpose of our analysis, and more specifically for the interpretation of our data, it is of utmost importance to be able to combine a more quantitative approach, deriving from Corpus Linguistics, with a more qualitative understanding. We therefore aim at

using corpora $[\ldots]$ and corpus processes $[\ldots]$ in order to uncover linguistic patterns which can enable us to make sense of the ways that language is used in the construction of discourses (or ways of construing reality). (Baker 2006: 1)

Corpus-assisted Discourse Studies, CADS, (Partington 2004; 2006; 2008) is a combination of quantitative and qualitative analytical techniques in the investigation of ad hoc specialized corpora. CADS analysts thus explore discourse features of a specific discourse type after becoming familiar with by way of concordancing data, reading single texts or excerpts, but also by resorting to external data, information regarding the wider context of text production and reception, and, of course, by relying on the researcher's own intuition.

Bayley (2008) proposes a theoretical framework that shares most of the assumptions of the CADS approach, which he names "corpus-assisted discourse analysis". Key meanings are identified by examining a corpus as a whole and they are subsequently explored by moving back and forth from text to corpus and vice versa (2008: 38). He points out that this kind of analysis is time-consuming, due to the complexity of the procedures and to the extensive knowledge of the corpus as a whole needed by the analysts following this approach (Bayley 2008: 39).

\subsection{Data analysis}

In order to proceed with the analysis, it has been decided to create a concordance for each lexeme, expand the concordances and analyze its co-text. The first step taken has been to look at collocates in order to see the relationship between the node word and the other lexical items in the corpus and try to understand how the co-text determines the use of the lexemes under investigation.

We decided to calculate collocates using the Log-likelihood procedure looking for a 5-word window to the left and right of the search term taking into consideration collocates having a minimum frequency that varies from 5 to 2 , depending on the 
frequency of the search term. This procedure looks quite similar to using rank by frequency, but the significance of the Log-likelihood scores makes it a more reliable procedure that takes into account the relationship between the search term and its collocates.

\section{Analysis of evaluative lexis}

\subsection{To bully}

The verb 'to bully' is the most frequent of the evaluative terms under investigation. In its inflected forms it occurs 144 times in the whole corpus, 136 referring to the Lisbon Treaty issue. The list of collocates contained in Table 2 clearly shows how the verb 'to bully' tends to be used with references to the Irish, people and voters, and to politicians and Governments. A closer reading of concordances is necessary to provide a better frame for interpretation.

\begin{tabular}{|c|c|c|c|}
\hline Word & Relation & Word & Relation \\
\hline Irish + & 123.32 & Voting $^{\circ}$ & 22.14 \\
\hline $\operatorname{Irish}^{\circ}$ & 103.60 & They + & 21.41 \\
\hline Ireland $^{\wedge}$ & 61.39 & Voting + & 20.87 \\
\hline Voters $^{\circ}$ & 49.17 & Government $^{\circ}$ & 20.18 \\
\hline Voters + & 46.11 & People ${ }^{\circ}$ & 19.59 \\
\hline Politicians $^{\circ}$ & 43.69 & Ireland $^{\circ}$ & 19.51 \\
\hline $\mathrm{He}^{\circ}$ & 43.10 & $\mathrm{EU}^{\circ}$ & 18.83 \\
\hline $\mathrm{We}^{\wedge}$ & 39.40 & They ${ }^{\wedge}$ & 17.87 \\
\hline $\mathrm{Us}^{\circ}$ & 33.92 & Government $^{\wedge} \wedge$ & 14.06 \\
\hline Voters $^{\wedge}$ & 32.71 & $\mathrm{He}^{\wedge}$ & 13.44 \\
\hline $\mathrm{He}+$ & 26.88 & Government + & 12.19 \\
\hline Ireland + & 24.56 & People + & 11.75 \\
\hline $\operatorname{Irish}^{\wedge}$ & 23.72 & & \\
\hline
\end{tabular}

Table 2: 'To bully’ collocates ordered by relation $\left({ }^{\circ}\right.$ bully, + bullying, ${ }^{\wedge}$ bullied $)$

Due to the relatively high number of occurrences and to the different syntactical patterns created by the inflected forms of the verb, these were examined separately in terms of who is the actor of the bullying and who is the victim, the goal of the process. We started by looking at the 57 concordances of bullying. As shown in Table $3^{2}$, the actors of the aggression seem to be explicitly identified as European institutions, EU politicians, France or the French President Nicholas Sarkozy, EU Council President at the Time, 41

\footnotetext{
${ }^{2}$ The terms listed in Tables 3, 4 and 5 represent a generalisation of the terms that were found to co-occur with each node word. For instance, occurrences such as EU Council President, EU politicians, EU leaders were added to the total of EU/Europe/Europeans in Table 3.
} 
times out of the total. In 35 out of 37 clearly identifiable goals, the victims of the bullying action are either the Irish people or voters, also referred to as we and us, or their politicians.

\begin{tabular}{llll}
\hline \multicolumn{1}{c}{ ACTORS } & \multicolumn{2}{c}{ GOALS } \\
\hline EU/Europe/Europeans & 18 & the Irish & 17 \\
France/French & 6 & Voters & 7 \\
(Irish) Government & 4 & Ireland & 4 \\
Brussels & 4 & Us/we & 4 \\
treaty (ratification) & 3 & Irish Government & 2 \\
(Irish) politicians & 3 & Irish leader & 1 \\
Both sides of the campaign & 2 & Smaller nations & 1 \\
Peter Mandelson & 1 & Central Europeans & 1 \\
Total & 41 & Total & 37 \\
\hline
\end{tabular}

Table 3: BULLYING

Example (1) clearly outlines the pattern that we had earlier identified: the leaders of the European Union are presented as the enforcers of a risky 'bullying' action against the Irish. The aggression is criticized and problematised by framing the action within a big "challenge". The rejection of the Treaty is presented as a fact, and the British Government, metonymically identified with "Downing Street" highlights that EU leaders are faced with the necessity of finding a way out. It is not clear though whether the negative evaluation of the response, "bullying the Irish", is a remark by the British Government or, more likely, a comment by the author of the article who is the Chief Political Correspondent for the Guardian.

(1) Downing Street argues that Ireland's rejection of the treaty in a referendum presents the EU's 27 leaders with a challenge which will not be resolved by bullying the Irish into voting yes. (the Guardian, 19 June 2008)

Table 4 refers to the analysis of the concordances of bullied, which was found 44 times in relation to the ratification of the Treaty. As the inflected form often occurs in passive constructions in our corpus, it's not always made explicit who the agent of the bullying process is. Nevertheless in 12 cases they are identified as $E U$ leaders or politicians. Another interesting pattern that has emerged is the cluster into supporting the treaty immediately following the node word. It seems that, since the actor has not always been made explicit, its the aim of the action that has been to compensate for the possible ambiguity. If the actor is not always present, the goal of the action receives a prominent position as the explicit subject of the grammatical construction. It is significant that in this relevant position ninety per cent (39 occurrences) of the concordances show the Irish and Ireland as the goals of the action.

\begin{tabular}{|c|c|c|}
\hline ACTORS & GOALS & \\
\hline by EU LEADERS/politicians & 12 Ireland (Country 1) & 10 \\
\hline nobody (2) anybody & $\begin{array}{l}3 \text { We (Irish) } \\
\text { (The Irish) people }\end{array}$ & $\begin{array}{l}8 \\
8\end{array}$ \\
\hline
\end{tabular}




\begin{tabular}{lll}
\hline \multicolumn{1}{c}{ ACTORS } & \multicolumn{1}{c}{ GOALS } \\
\hline & (The Irish) voters & 5 \\
& (The Irish) Governement & 3 \\
& The Irish & 2 \\
& Residents [Dublin] & 1 \\
& Electorate & 1 \\
Total & Dublin & 1 \\
& 15 Total & 39 \\
\hline
\end{tabular}

Table 4: BULLIED

The passive construction "we won't be bullied", in "Example (2), proves that even in those cases were the actor is not explicitly mentioned it is not difficult to infer who s/he is by the immediate co-text. "Irish voters", the targets of the "bullying' action, are also the active participants of another action. Their vote has "sent a clear message" to European Institutions, "Brussels", that can therefore be inferred as the actors of the bullying action also by referring to the slogan of the EU, i.e. an "ever closer union". The force of their action arises also for the phrase 'to send a (clear) message' which has been analyzed as having the function of a threat (Riccio 2009)

(2) Irish voters sent a clear message to Brussels last week: we won't be bullied into "ever closer union". And if you had any doubts that voting against the Lisbon treaty was the right decision, then the reaction following Thursday's vote should have put those to rest. (The Sunday Times, 15 June 2008)

'Bully', either as an infinitive or modified by modal auxiliaries, occurs 35 times and always with reference to the Lisbon Treaty. As Table 5 makes clear, the Irish, identified as voters, electorate, people, us, them, Ireland, are always the explicit goal of the action. EU politicians, French ones in particular, British and Irish ones are those to blame in 32 out of 35 cases, i.e. the vast majority of the occurrences.

\begin{tabular}{llll}
\hline \multicolumn{1}{c}{ ACTORS } & \multicolumn{2}{c}{ GOALS } \\
\hline French & 8 & the Irish & 12 \\
EU politicians & 5 & Voters (Irish voters) & 7 \\
Prime Minister (Brown 2$)$ & 4 & Us (the Irish) & 5 \\
EU leaders (elites 2) & 4 & Ireland & 4 \\
European politicians & 3 & them [The Irish] & 3 \\
Ratification & 2 & Irish & 2 \\
Government & 2 & People & 1 \\
Brussels & 1 & Electorate & 1 \\
European commission & 1 & & \\
Cowen & 1 & & \\
EU & 1 & \\
Total & 32 & Total \\
\hline
\end{tabular}

Table 5: BULLY 
In example (3), taken from the Daily Mail, the French foreign minister, Bernar Kouchner, is depicted as the "latest" in a series of members of the "European political establishment" who has tried 'to bully' the Irish voters. As explained earlier in section 1, the French politicians have had a particularly active role in the aftermath of the referendum due to the French presidency of the European Council in the second semester of 2008.

(3) They [Irish citizens] know, too, that the eyes of the European political establishment are on them. Bernard Kouchner, the French foreign minister, is the latest outsider to attempt to bully the electorate. (Daily Mail, 13 June 2008)

The analysis has shown that the verb "to bully" is systematically used within the same conceptual frame, partially regardless of the different grammatical and syntactic features of the inflected forms. EU institutions and their leaders, with a particular emphasis on French politicians, are the 'bullies' who, regardless of the results of the referendum, are seeking ways of forcing the Irish into accepting the Lisbon Treaty. This negative connotation of the 'bullying' action is often reinforced by other elements, in the immediate co-text, that suggest a negative evaluation of the process, e.g. the phrase "sent a clear message" in example (2) or the term "outsider" to describe the French minister in example (3).

By looking at the temporal distribution of the occurrences of "to bully" we can say that they cluster around the time of the Irish referendum and immediately afterwards. There are 90 occurrences of "to bully" in July 2008 and 27 ones in the following month; together they account for more that $80 \%$ of the total 136 occurrences of the verb. These two months represent the period when the Irish received greater pressure from 'Europe' to accept the treaty first, and to find a solution to the 'no' vote afterwards. Another interesting observations stems from the distribution of the occurrences among the newspapers. More than $50 \%$ of the occurrences were found in the Daily Mail and The Sun (45 and 25 occurrences respectively), two newspapers who have been proven to have a rather Eurosceptic attitude (Anderson \& Weymouth 1999). It is worth remembering that The Sun in particular had campaigned in favor of a British referendum.

\subsection{To blast}

The verb 'to blast' in its metaphorical meaning of 'to explode in criticism' occurs 13 times in the whole corpus. As it is clear from its collocates, having at least three occurrences in the corpus, criticism arose between campaigners and political leaders, especially Cowen and Brown (see Table 6).

\begin{tabular}{ll}
\hline \multicolumn{1}{c}{ Word } & Relation \\
\hline FOR & 38.081 \\
NO & 32.445 \\
CLAIMING & 28.791 \\
CAMP & 24.825 \\
RECENT & 24.495
\end{tabular}




\begin{tabular}{ll}
\hline \multicolumn{1}{c}{ Word } & Relation \\
\hline ANTI & 21.32 \\
LISBON & 21.21 \\
TAOISEACH & 20.049 \\
COWEN & 18.247 \\
CAMPAIGN & 17.768 \\
OVER & 17.163 \\
BROWN & 17.03 \\
MR & 14.071 \\
WAS & 11.976 \\
TREATY & 10.215 \\
\hline
\end{tabular}

Table 6: 'blast' collocates ordered by relation

A closer reading of the concordances has revealed that the major cause of blast is the continuous support for the Treaty and its ratification despite the rejection of the Irish people. The goals of the criticism are mainly pro-EU politicians eight out of twelve goals are in fact supporters of the European project. On the other hand only four times the $N O$ camp or $N O$ voters appear to be the goals of the action, criticized for their claims against the approval of the Treaty.

(4) The No campaign blasted eurocrats in the run up to the referendum for trying to bully the Irish into voting Yes when most people did not understand what it would mean. (The Sun, 11 July 2008)

The example above clearly shows a strong disapproval of the European decision of continuing with the ratification and convincing the Irish people to vote in favor of the Treaty at the next ballot. The negative attitude towards the EU's action is not only expressed by the verb 'to blast' but is also reinforced by the verb 'to bully' and the contrast between the forced action and people's unconsciousness of the consequences of a positive outcome. Moreover, the co-occurrence of the two evaluative verbs help the journalist to create coherence and to construe the news story conferring EU politicians the image of disrespectful leaders.

The analysis has revealed that the verb 'to blast' mainly appears in The Sun which shows seven occurrences. This does not surprise considering the fact that The Sun advocated the referendum cause in Britain and is known to be anti-European. As it might be expected, the majority of the occurrences (seven) appear around the first referendum period i.e. between May and July 2008.

In conclusion, the analysis has shown how the verb 'to blast' in its meaning of explode in criticism is used in order to reveal a negative evaluation of the European politicians and attributing them the role of careless leaders only interested in achieving their purposes. 


\subsection{Arrogant}

As far as the lexical item 'arrogant' is concerned, we have found that it occurs 47 times, 46 referring to the Lisbon Treaty issue.

The collocates, having at least three occurrences in the corpus, that we identified are shown in Table 7 below.

\begin{tabular}{llll}
\hline Arrogant & \multicolumn{3}{l}{ Reluctant } \\
Word & Relation & Word & Relation \\
\hline INTERVENTION & 50.97 & CLINTONS & 40.90 \\
PRESIDENT & 42.38 & RECOGNISE & 26.65 \\
BARROSO & 36.94 & EXTREMELY & 25.69 \\
FRENCH & 35.23 & RISK & 21.60 \\
MANUEL & 29.27 & DEFEAT & 21.22 \\
ACCUSED & 28.85 & FURTHER & 17.89 \\
JOSE & 28.76 & GIVE & 16.98 \\
LABOUR & 27.94 & AGAIN & 15.68 \\
WARNED & 26.92 & MANY & 14.64 \\
PLAN & 25.27 & SECOND & 14.33 \\
EU & 25.05 & LEADERS & 13.98 \\
HAD & 21.38 & COWEN & 13.07 \\
SARKOZY & 19.05 & THEY & 8.66 \\
SOME & 18.41 & REFERENDUM & 8.65 \\
BEING & 18.31 & LISBON & 7.14 \\
MR & 17.78 & TREATY & 5.32 \\
OUT & 14.62 & & \\
WAS & 13.76 & & \\
HAS & 10.02 & & \\
LISBON & 8.94 & & \\
TREATY & 6.29 & & \\
THAT & 4.63 & & \\
\hline
\end{tabular}

Table 7: 'Arrogant' and 'reluctant' collocates ordered by relation

On the basis of these collocates, it has been possible to make some observations. It appears that 'arrogant' mainly collocates with European leaders and in particular with Barroso and Sarkozy, however in order to understand its use it has been necessary to sort and expand the concordances. A more detailed analysis of the term has been carried out through the investigation of its attributive and predicative functions which are going to be discussed in turn.

It has emerged that the adjective occurs 33 times as an attribute and 14 times as a predicate. The analysis has proved that as an attribute the lexical item mainly refers to EU leaders, and in particular to the French Prime Minister Sarkozy and his intervention on the Irish government announcing a second Irish vote. The Irish Prime Minister Cowen and his government, the president of the European Commission, Barroso, and the British Prime Minister, Gordon Brown, are also described as 'arrogant' (Table 8). 


\begin{tabular}{llll}
\hline \multicolumn{1}{c}{ attributive position } & \multicolumn{1}{c}{ predicative position } \\
\hline EU leaders (in general) & 8 & EU response (to referendum result) & 2 \\
the French intervention & 4 & Labour & 2 \\
Barroso & 3 & Roche's plan & 2 \\
the French president & 3 & Politicians & 1 \\
Brown's plan (s)/attempt & 3 & Cowen & 1 \\
Cowen & 2 & Germany & 1 \\
Irish Government & 2 & EU & 1 \\
Stuff (EU's new power with Treaty's & & & \\
approval) & 1 & Bertie & 1 \\
Yes body & 1 & Barroso & \\
& & the move (the ratification of Lisbon & \\
Campaign & 1 & without Ireland) & \\
Cowardice (vote denial) & 1 & & \\
Dismissal (of Irish vote) & 1 & & \\
Insult (Irish Politicians did not read & & & \\
the treaty) & 1 & & \\
Nonsense (propose a 2nd vote) & 1 & & \\
Ministers & 1 & & \\
Total & 33 Total & & \\
\hline
\end{tabular}

Table 8: 'Arrogant' in attributive and predicative position

The emphasis appears to be on the actors/promoters of the ratification process and on the fact that their proposal of ratifying Lisbon didn't take into account the will of their citizens. These leaders and their action appear to be the focus of the British press which seems to negatively evaluate their role in the event.

(5) ARROGANT EU president Jose Manuel Barroso last night vowed to push on with the Lisbon Treaty - even though Ireland emphatically REJECTED it. We dumped the deal by 53.4 per cent to 46.6 per cent - a majority of nearly SEVEN per cent. It is now DEAD under EU rules. (The Sun, 14 June 2008)

(6) The French president even plans a visit to Dublin next month to see what all the fuss is about and to use his charm to try to ensure the "right" result next time. After all, how could Ireland, alone of those 27 member countries, have found fault with the treaty? It is nonsense; and it is arrogant, insulting nonsense. Ireland rejected the treaty because it was the only country whose people got to vote on it. (The Sunday Times, 22 June 2008)

The lexeme 'arrogant' generally denotes a manifestation of an overbearing attitude and is often associated to negative connotation. In example (5) this negativity seems to be reinforced by the contrastive evaluator 'even though' which puts in contrast Barroso's choice of continuing with ratification and Ireland people's decision of voting against the Treaty. The contrast is also emphasized by the fact that both 'arrogant' and 'rejected' are in capital letters. As a result, this contrast puts Barroso in a negative light and confers him the image of a disrespectful leader. Moreover, the negative stance of the newspaper 
towards the EU leader and the ratification of Lisbon is clearly visible in the expression "it is now DEAD under EU rules" which puts emphasis on the illegality of ratifying the Treaty without the Irish approval. The use of 'DEAD' in capitals in fact seems to reveal the newspaper's serious consideration for a ratification suspension.

In example (6) the negative evaluation of Sarkozy's intent on persuading the Irish people to vote in favour of the treaty at the next ballot is emphasized by the collocation of the adjective 'arrogant' with the noun phrase 'insulting nonsense'. This collocation might suggest a disapproval of EU leaders', and in particular Sarkozy's, contempt for the Irish people's will.

The disapproval of Sarkozy's plans of action is also revealed by the ironical use of the lexeme 'charm' and the rhetorical question. Moreover, the use of the adjective 'right' in inverted comas might suggest negative stance towards the fact that EU leaders have not accepted the Irish NO but are still intent on pursuing their aim.

Similar results have been revealed by the analysis of 'arrogant' as a predicate. Although there are fewer occurrences, it has emerged that 'arrogant' refers to EU leaders and politicians' behavior and attitude towards the referendum response or their obstinacy to ratify Lisbon as shown in Table 8 above.

It has also emerged that political figures and manly newspapers opposing the ratification refer to proponents or supporters of the Treaty as 'arrogant' because they are ignoring the Irish people's decision and democracy in general.

(7) European Union reform was plunged into chaos last month when the Lisbon Treaty was rejected in an Irish referendum by 53.4 per cent to 46.6 per cent. Open Europe's Mr O'Brien said the political response to the referendum result had obviously appeared arrogant to some voters. (Daily Mail, 28 July 2008)

(8) Fine Gael branded Mr Roche's plan arrogant while Labour warned it could force more into the No camp. Fine Gael's Lucinda Creighton said: "It is clear the Irish people said no and that verdict must be respected. "The fundamental concerns of the Irish people cannot be brazenly ignored by Dick Roche, Brian Cowen or anyone else". (Mirror, 26 August 2008)

In both examples above, what is referred to as 'arrogant' is the decision of holding a second referendum in Ireland. Both newspapers seem not to be taking responsibility for what politicians are saying. In example (7) in fact the journalist is attributing the evaluation to the director of the British think-thank Open Europe, O'Brien, while in example (8) the journalist is quoting Lucinda Creighton's statement. However, the journalist of the Daily Mail appears to be slightly more involved than the one of the Mirror. In his use of the evaluative adverb 'obviously' he seems to be evaluating the reaction of voters in terms of evidentiality as if their consideration of EU leaders' pressure on a second vote could only be referred to as 'arrogant'. This might imply the journalist' disapproval of that action.

The analysis has proved that 'arrogant' is used with reference mainly to European leaders and their obstinacy to ratify the Treaty even after the Irish negative result in the referendum. The lexeme has shown to be linked to negative stance and in this context its negative meaning is reinforced by other intensifiers and evaluative terms. It has emerged that 'arrogant' mainly occurs around the first referendum period and to be precise 35 out 
of 47 occurrences appear between May and August 2008 with a pitch in June (21 occurrences). Moreover, the analysis of its occurrences has revealed that the adjective mainly appears in The Sun with 15 occurrences, the Daily Mail with 13 occurrences and The Times with 8 occurrences.

This comes as no surprise considering the fact that other studies have proved that these newspapers are eurosceptics (Anderson \& Weymouth 1999). Moreover, from a general reading of the corpus it has also emerged that those newspapers, The Sun in particular, advocated a referendum in Britain.

In conclusion, the analysis has revealed that the adjective 'arrogant' is used both as a predicate and an attribute to convey a general negative attitude towards EU leaders and their projects.

\subsection{Reluctant}

A similar analysis has been carried out for the evaluative adjective 'reluctant'. It has emerged that there are 23 occurrences 21 of which refer to European issues. Five appear in attributive position while the other sixteen are in predicative position. Looking at its collocates, having at least two occurrences in the corpus (see Table 7), it has not been possible to make many observations apart from the consideration that Cowen and leaders as frequent collocates might be 'reluctant' to do something. As a consequence, in order to make significant hypotheses on the use of this lexeme it has been necessary to explore its co-text. A deeper analysis has proved that as an attribute the adjective 'reluctant' refers to different politicians such as Gordon Brown or the Irish members of the government which seems to be goals of EU leaders' action. In its predicative position 'reluctant' has found to co-occur mainly with EU leaders, the British Prime Minister, Brown and the Irish Prime Minister, Cowen (see Table 9).

\begin{tabular}{lll}
\hline attributive position & predicative position & \\
\hline horses (Irish Governement members) & 1 Brown & 3 \\
Leaders & 1 Brussels & 2 \\
populations (The Germans and French) & 1 Cowen & 2 \\
paramour (is compared to Sarkozy) & 1 Most EU members & 1 \\
Partner (Brown) & 1 they (politicians) & 1 \\
& it (Irish Gov) & 1 \\
& Many EU politicians & 1 \\
& Cameron & 1 \\
& Eurocrats & 1 \\
& they (people) & 1 \\
& Sarkozy & 1 \\
Total & EU leaders & 1 \\
& 5 Total & 16 \\
\hline
\end{tabular}

Table 9: 'Reluctant' in attributive and predicative position

It has emerged that there are twofold reasons for being 'reluctant' - politicians are reluctant to abandon the treaty and to hold a second referendum. The collocation of EU 
politicians with this adjective, here functioning as predicate, might imply their ambivalence in approaching the issue of ratification. On the one hand, their reluctance to hold a referendum might suggest that they are afraid of a second negative turnout while on the other hand, their reluctance to abandon the treaty might imply a strong determination in pursuing their political goals.

(9) What may happen next? There will be an attempt to rescue the substance of the Lisbon treaty in some form or through some subterfuge. Brussels, like the Clintons, is extremely reluctant to recognise defeat. The European politicians want their legal identity, their extended powers, their president, their foreign minister. They want the status of a national state. (The Times, 16 June 2008)

In example (9) the reluctance to abandon the treaty is emphasized by the metaphorical expression 'recognise defeat' which is taken from the field of conflict and clearly expresses the fact that despite a negative turnout EU leaders, metonymically referred to as Brussels, are intent on reaching their political goal whatever it might happen. This obstinacy seems to be also reinforced by the evaluative adverb 'extremely'. In the use of the metaphor and the evaluative adverb, the newspaper is clearly disapproving of EU leaders' action and seems to confer them a negative connotation.

The analysis has also revealed that 13 out of 21 occurrences of 'reluctant' appear in June 2008, i.e. around the referendum period and the following approval of the Treaty bill in the House of Lords. Moreover, the Daily Mail and The Times are the newspapers in which this lexeme is more frequent and in particular, with 7 and 6 occurrences respectively.

The fact that 'reluctant' frequently appears in the Daily Mail and The Times does not surprise. As it has already been mentioned (see 'arrogant' analysis) these newspapers have been proved to be anti-European.

As shown in the analysis, the lexeme 'reluctant' has proved to be used in order to convey a negative image of EU leaders and their way of handling the suspension of the ratification after the Irish negative vote.

\subsection{Praise}

The analysis conducted in the previous paragraphs has only focused on evaluative lexis that has a negative meaning and reveals negative connotation. In this section we will explore the verb 'to praise' and its noun form which have a positive meaning and are generally linked to a positive evaluation. The analysis has revealed 34 occurrences 27 of which refer to European issues and the collocates, having a minimum frequency of two, are shown in Table 10 below.

\begin{tabular}{llll}
\hline \multicolumn{1}{c}{ Word } & \multicolumn{1}{c}{ Relation } & \multicolumn{1}{c}{ Word } & Relation \\
\hline LAVISHED $^{\wedge}$ & 56.735 & LEADERS $^{\wedge}$ & 15.244 \\
COURAGE + & 42.568 & WHO $^{\wedge}$ & 11.637 \\
EU $^{\wedge}$ & 29.906 & MR $^{+}$ & 11.329 \\
GORDON + & 29.466 & IRELAND $^{\wedge}$ & 11.167
\end{tabular}




\begin{tabular}{|c|c|c|c|}
\hline Word & Relation & Word & Relation \\
\hline DESERVES ^ & 29.177 & $\mathrm{MR}^{\wedge}$ & 10.206 \\
\hline $\mathrm{PRESIDENT}^{\wedge}$ & 25.054 & $\mathrm{THEY}^{\wedge}$ & 9.890 \\
\hline $\mathrm{PM}^{\wedge}$ & 24.074 & $\mathrm{HIS} \wedge$ & 9.765 \\
\hline BROWN + & 22.290 & WAS + & 9.265 \\
\hline $\mathrm{BROWN}^{\wedge}$ & 18.163 & $\mathrm{HE}+$ & 8.740 \\
\hline GANLEY + & 16.389 & $\mathrm{NOT}^{\wedge}$ & 8.646 \\
\hline LEADERS + & 16.370 & $\mathrm{WITH}^{\wedge}$ & 8.632 \\
\hline SARKOZY + & 16.292 & $\mathrm{HE}^{\wedge}$ & 6.473 \\
\hline $\mathrm{EU}+$ & 15.302 & TREATY $^{\wedge}$ & 5.829 \\
\hline YESTERDAY + & 56.735 & $\mathrm{TO}^{\wedge}$ & 15.244 \\
\hline
\end{tabular}

Table 10: 'Praise’ collocates $\left({ }^{\wedge}\right.$ praise,+ praised $)$

It has emerged that 'praised' mainly collocates with the EU or its leaders and other important participants in the ratification process: the British Prime Minister Brown, the French President Sarkozy, who took the EU rotating presidency in July 2008, and Mr. Declan Ganley the founder of the Irish anti-Lisbon Libertas group. The Table also shows that 'praise' not only collocates with 'EU', 'Brown' and 'leaders' but also with 'Treaty', 'Ireland' and verbs such as 'deserves' and 'lavished'. As far as 'praise' is concerned, these collocates seem to suggest that when it co-occurs with singular nouns these are the goals of the action but the actors are not clear. The same difficulty is found with the collocates of 'praised' as it can be both the past form and the past participle of the verb. As a result, an analysis of the co-text has been necessary in order to help us understand the use of 'praise' and its actors and goals (see Table 11).

\begin{tabular}{llll}
\hline GOALS & & GOALS & \\
\hline EU LEADERS & 8 & Brown & 8 \\
Sarkozy & 4 & Ireland/Irish (voters/government) & 4 \\
Eurosceptics (the Czech President) & 4 & Eurosceptics (Ganley, Kaczynski) & 4 \\
Brown & 3 & Cowen & 3 \\
Press & 2 & Treaty & 2 \\
Barroso & 1 & EU & 1 \\
& & Barroso & 1 \\
Total & 22 & Total & 23 \\
\hline
\end{tabular}

Table 11: Actors and Goals of 'praise'

The analysis of the co-text has revealed that the actors of the verb 'praise' or the expressions 'showered with praise' or 'lavished with praise' are mainly EU leaders and politicians and their goals are Gordon Brown and Brian Cowen's courage in continuing with ratification or finding a way towards its completion. These occurrences appear as attributions of EU leaders and the journalists tend to negatively comment their action of praising. 
(10) And they [EU bigwigs] PRAISED Premier Gordon Brown's "courage" for ramming the hated document through Parliament with no referendum. (The Sun, 20 June 2008)

(11) IRELAND was under growing pressure to roll over and accept the Lisbon Treaty last night after voters rejected it, as EU leaders scrambled to find a way out of the crisis. In a provocative move, they lavished praise on Gordon Brown for the 'political courage' he showed in forcing ratification of the treaty through Parliament despite last Friday's decisive 'no' vote in Ireland. (Daily Mail, 20 June 2008)

In both examples the action of praising Brown's decision of continuing with ratification is put in contrast with the will of the British and Irish people respectively by using the expression 'with no referendum' in example (10) and the contrastive evaluator 'despite' in example (11). In other words newspapers appear to indicate that Brown's behavior, and as a consequence Europeans' approval of it, is a contempt for democracy in general. The negative stance of the two newspapers towards Brown's action is reinforced by the use of inverted commas for the noun courage implying that continuing with ratification is not a courageous way of accepting the decision made by the Irish and British citizens. Moreover, in both newspapers the action of ratifying the treaty is expressed by two verbs 'ram trough' and 'force through' which indicate an intentionally forced action. Even though from one hand the fact that Brown is the actor of both verbs confers him an important role in the process of ratification and also an active role in the news story, on the other hand, it gives him the image of an enforcer and as a consequence, it confers him a negative evaluation.

The analysis has also proved that when the actor of the verb 'to praise' or the other constructions is a Eurosceptic, the goal is the rejection or anti-Lisbon actions. In these occurrences it has emerged that the action of praising is positively evaluated.

(12) His [Kaczynski's] remarks, which came as France took over the EU's six month rotating presidency, won praise from eurosceptics, who are convinced that Brussels is trying to bully Ireland into voting again.(Daily Mail, 2 July 2008)

(13) CZECH president Vaclav Klaus praised Libertas founder Declan Ganley last night and attacked the EU as having made a 'radical shift' from integration to supranationalism.(Daily Mail, 12 November 2008)

In example (12) while Kaczynski's remarks appear to be laudable on the other hand EU leaders are described in a negative light as bullies forcing Ireland to vote again. In this example, even though the newspaper seems not to take responsibility for the eurosceptics' praise or convictions it does not negatively comment their claims. In example (13) too, the newspaper limits to report the praise and criticism of the Czech President without deeply commenting on them. However, the action of praising is put in contrast with the EU's approval of the Lisbon plans that has determined, according to the newspaper, a shift from integration to supranationalism. This might suggest a disapproval of EU leaders' action and as a consequence might imply a positive stance towards the president's laud of Declan Ganley. 
From the analysis it has also emerged that the lexeme 'praise' is more equally distributed in the newspapers than the other evaluative terms. However further more occurrences appear in the Daily Mail and in The Sun which as it has already been said are known to be part of the British Eurosceptic press. And precisely, the Daily Mail shows 7 occurrences while The Sun 5. It has also come into light that 15 out of 27 occurrences of 'praise' appear between May and July 2008, i.e. again around the first referendum period and also during the British approval of the Treaty bill in the House of Lords. Other 6 occurrences are also found between October and December 2008, i.e. when EU leaders were deciding how to grant Ireland's guarantees in the field of tax policy, neutrality and abortion in order to have the second referendum run.

The analysis has revealed that even though the lexeme 'praise' has a positive denotation, it might be used to convey a negative connotation of those European leaders that tend not to express consideration for the will of their citizens. On the other hand, it appears to be used in a positive way when the action of praising is the expression of those who try to defend the interests of the Irish people.

\section{Conclusions}

In our analysis we have also focused on the distribution of the evaluative terms in the newspapers' sections and occurrences of the same lexeme that appeared in the same article were only counted once. We labeled newspapers' sections as non hard news referring to editorials, comments and features while as hard news all the other sections. As it is strictly linked to the writer's opinions and feelings, evaluative lexis is expected to be found in editorials and comments rather than in hard news. In our analysis we have found that the occurrences of evaluative terms under investigation mainly appear in hard news as shown in Figure 1.

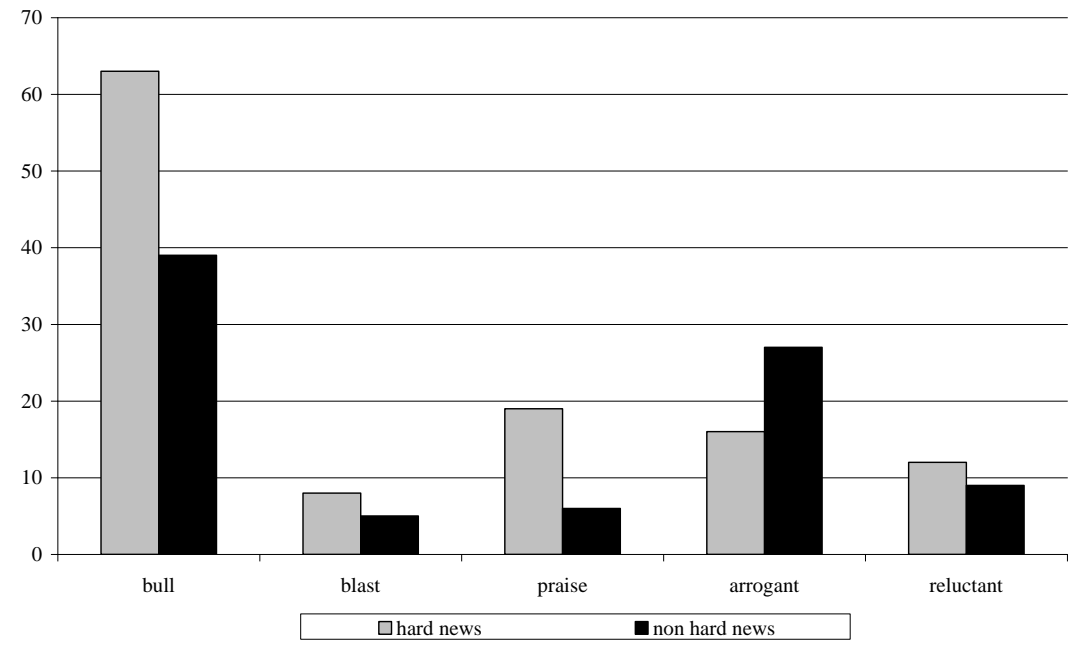

Figure 1: Hard news/non-hard news distribution 
As it is shown in Figure 1 only arrogant has a majority of occurrences appearing in non hard news while the other lexemes are more frequent in hard news. The fact that those evaluative resources tend to be slightly more frequent in hard news might imply that the Lisbon Treaty ratification has been a much debated issue and as a consequence its reports could not be only limited to a specific section.

In conclusion, the present study has shown how through a co-text and context-based analysis of evaluative lexis it has been possible to build a conceptual frame of the ratification process which appears to confirm the previous analysis conducted on the same corpus which has revealed that EU leaders and pro-European politicians were stereotyped in terms of aggressors using bullying tactics while Ireland and the Irish people were described as victims of EU leaders.

\section{References}

Anderson, Peter J. \& Tony Weymouth (1999). Insulting the Public? The British press and the European Union. London and New York: Longman

Baker, Paul (2006) Using corpora in discourse analysis. London: Continuum International Publishing Group Ltd.

Bayley, Paul (2008). 'Weakness and fear. A fragment of corpus-assisted discourse analysis' in A. Martelli and V. Pulcini (eds.), Investigating english with corpora. Studies in honour of Maria Teresa Prat, Monza: Polimetrica, 37-53.

Bednarek, Monika (2006). Evaluation in Media Discourse. Analysis of a Newspaper Corpus. London/New York: Continuum.

Bell, Allan \& Peter Garrett (Eds.) (1998). Approaches to Media Discourse. Oxford: Blackwell.

Charteris-Black, Jonathan (2004) Corpus Approaches to Critical Metaphor Analysis. Basingstoke:Palgrave.

Fowler, Roger (1991). Language in the News. Discourse and Ideology in the Press, London/New York, Routledge.

Goatly, Andrew (1997). The Languages of Metaphors. London: Routledge

Hunston, Susan \& Thompson, Geoff (2000). (eds.) Evaluation in Text. Oxford: OUP.

Lakoff, George \& Mark Johnson (2003). Metaphors We Live By. Chicago: University of Chicago Press.

Musolff, Andreas (1996). 'False Friends Borrowing the Right Words? Common Terms and Metaphors in European Communication' in A. Musolff, C. Schäffner, \& M. Townson, (eds.) Conceiving of Europe: Diversity in Unity, Aldershot: Dartmout, 1530.

Musolff, Andreas (2000) 'Political Imagery of Europe: a house without exit doors?'. Journal of Multilingual and Multicultural Development, 21 (3), 216-229.

Musolff, Andreas (2001) 'The Metaphorisation of European Politics: Movement on the Road to Europe' in A. Musolff, C. Good, P. Points \& R. Wittlinger (eds). Attitudes towards Europe: language in the unification process, Aldershot/Burlinghton USA/Singapore/Sydney: Ashgate, 179-200

Musolff, Andreas. (2004). Metaphor and Political Discourse. Analogical reasoning in Debates About Europe. New York: Palgrave Macmillan. 
Nasti, Chiara (2010) Images of the Lisbon Treaty Debate in the British Press. A Corpusbased Approach to Metaphor Analysis. Unpublished.

Partington, Alan (2004) 'Corpora and discourse, a most congruous beast', in L. Haarman, J. Morley and A. Partington (eds), Corpora and Discourse, Bern: Peter Lang, 11-19.

Partington, Alan (2006) The Linguistics of Political Laughter: a corpus-assisted study of laughtertalk. London and New York: Routledge.

Partington, Alan (2008) 'The armchair and the machine: Corpus-assisted discourse research', in C. Taylor Torsello, K. Ackerley and E. Castello (eds.), Corpora for University Language Teachers, Bern: Peter Lang, 95-118.

Riccio, Giulia (2009) 'White House press briefings as a message to the world', in P. Bayley and J. Morley (eds.) Wordings of War: Corpus-assisted discourse studies on the Iraq conflict, London; New York: Routledge, 108-140.

Schäffner, Christina (1996). 'Building a European House? Or at Two Speeds into a Dead End? Metaphors in the Debate on the United Europe' in A. Musolff, C. Schäffner, \& M. Townson, (eds.) Conceiving of Europe: Diversity in Unity, Aldershot: Dartmout, 31-59.

Scott, Michael. (2008). WordSmith Tools version 5. Liverpool: Lexical Analysis Software.

Semino, Elena. (2002). 'A sturdy baby or a derailing train? Metaphorical representations of the euro in British and Italian newspapers'. Text, 22, 107-139. 